\title{
Intertidal habitat use of bottlenose dolphins (Tursiops truncatus) in Bahía San Antonio, Argentina
}

Els Vermeulen

\author{
Mammal Research Institute, University of Pretoria, cnr Lynnwood Road and Roper Street, Hatfield, South Africa. \\ Whalefish, 2/10/72 Lancefield Quay, Glasgow G38JF, United Kingdom \\ Sea Search, 4 Bath road, Muizenberg, Cape Town South Africa \\ Contact: elsvermeulen5@gmail.com / +27609714301
}

\section{Abstract}

Very little information is available on bottlenose dolphin (Tursiops truncatus) habitat use in the Southwestern Atlantic. It is, however, essential in understanding their ecology and improve conservation management. In this study, habitat use of bottlenose dolphins was examined in Bahía San Antonio, an area frequented by the species. Given the large tidal amplitude and extended intertidal zone in this bay, special focus was given to the intertidal vs. subtidal habitat use patterns.

Bottlenose dolphins were observed in only half of the surveyed area, with on average 1 dolphin group encountered per $100 \mathrm{~km}$ surveyed. All dolphin groups were seen in shallow waters $<10 \mathrm{~m}$ deep. GLM analyses showed that especially during high tide, depth had an important effect on the dolphin encounter rate, with most dolphin groups encountered in the intertidal zone. While in the intertidal zone, most dolphin groups were observed to be engaged in surface feeding activities.

The presented data indicate dolphins remained in shallow waters, and moved to the intertidal zone during high tide where they appear to find feeding opportunities. This information is believed to be of high value in understanding this population's ecological needs, and essential when aiming to improve marine conservation efforts at times of increased anthropogenic pressures in the area.

KEYWORDS: bottlenose dolphin, coastal habitat, environmental variables, habitat use, intertidal zone 


\section{INTRODUCTION}

Cetaceans, including bottlenose dolphins (Tursiops truncatus), live in complex habitats with a dynamic regime of physical and chemical properties (Bräger et al., 2003). The relationship between coastal bottlenose dolphins and their habitat differs largely among regions. Some coastal populations were shown to perform seasonal movements from deeper channels to shallow waters (e.g. Waples, 1995), whereas others indicated preferences for estuarine habitats (e.g. Shane, 1990; Ballance, 1992; Hanson \& Defran, 1993; Scott et al., 1996). Other studies indicated a high correlation between dolphin occurrence and water depth, often with a preference for shallow waters (e.g. Cañadas et al., 2002; Bearzi, 2005; Blasi \& Boitani, 2012). An increased use of steep slopes has also been documented, suggested to facilitate the dolphins' feeding activities (Ingram \& Rogan, 2002; Cañadas et al., 2005). Overall, most studies indicated habitat use of bottlenose dolphins is mainly driven by prey distribution and abundance, sometimes in combination with predation risk (e.g. Shane, 1990; Ballance, 1992; Hanson \& Defran, 1993; Waples, 1995; Scott et al., 1996).

To date, only one study has assessed bottlenose dolphin habitat use in Argentina (Würsig \& Würsig, 1979). According to the authors, bottlenose dolphin movements in Golfo San José were related to the tide. Dolphins seemed to stay in shallower water as the tide retreated, until they needed to go to deeper waters when the tide was too low. Another community of bottlenose dolphins is known to range further up north, with a core area in Bahía San Antonio (BSA) (Vermeulen \& Cammareri, 2009; Vermeulen et al., 2016). This population was reported to be small and declining (Vermeulen and Bräger, 2015).

In general, BSA is of great ecological value due to its high biodiversity, not only harbouring a community of resident bottlenose dolphins (Vermeulen et al., 2016) but also being an important spawning and nursing area for many fish species (Perier, 1994), and one of the most important resting and feeding sites of the Southwestern Atlantic Ocean for several migratory bird species (González et al., 1996). However, although the area was declared a 'Natural Reserve' in Argentina by provincial law 2670 of June 1993, the area is still designated for 'multiple use' and includes one of the largest port of Argentina, a chemical plant producing sodium carbonate, as well as artisanal and recreational fishing activities, and whale- and dolphin-watching activities (Giaccardi and Reyes, 2012). Additionally, BSA is the most important touristic destination along the coast of Northeast Patagonia, with three expanding towns under the municipality of San Antonio: 1) San Antonio Oeste 2) San Antonio Este and 3) Las Grutas. 
In general, various authors have stated that the rapid demographic and industrial growth along the Patagonian coast is resulting in increased pressures on the natural resources (Peralta, 1998; Boltovskoy, 2009; González and Benseny, 2013). In view of this, the present study aims to investigate the habitat use patterns of the local declining bottlenose dolphin population in BSA. As the area is known for its large tidal amplitude and extended intertidal zone, special focus was placed on the dolphin's intertidal vs. subtidal habitat use. The information presented here is believed to be highly valuable for understanding the ecological needs of this population of dolphins, and essential for improved conservation management in the area in times of increased coastal urban and industrial developments.

\section{MATERIAL AND METHODS}

\section{Study area}

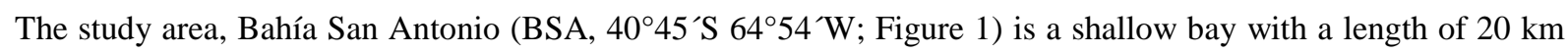
in the East-West direction, a width of $10 \mathrm{~km}$ North-South, an average depth of $6 \mathrm{~m}$ and a maximum depth not exceeding $30 \mathrm{~m}$ (SHN, 2000). With a surface area of approximately $655 \mathrm{~km}^{2}$, the bay is known for its large tidal differences (Perier, 1994; SHN, 2000). The tidal regime is semidiurnal and the tidal amplitude varies between $6.5 \mathrm{~m}$ at neap and $9.3 \mathrm{~m}$ at spring tide (average $\pm 8.3 \mathrm{~m}$ ), leaving up to $86 \%$ of the total surface of the bay exposed during low tide (SHN, 2000; Perier, 1994). The region is characterised by different types of intertidal habitat, with sandy beaches and rocky flats (up to $800 \mathrm{~m}$ wide) covering the majority of the area (González et al., 1996).

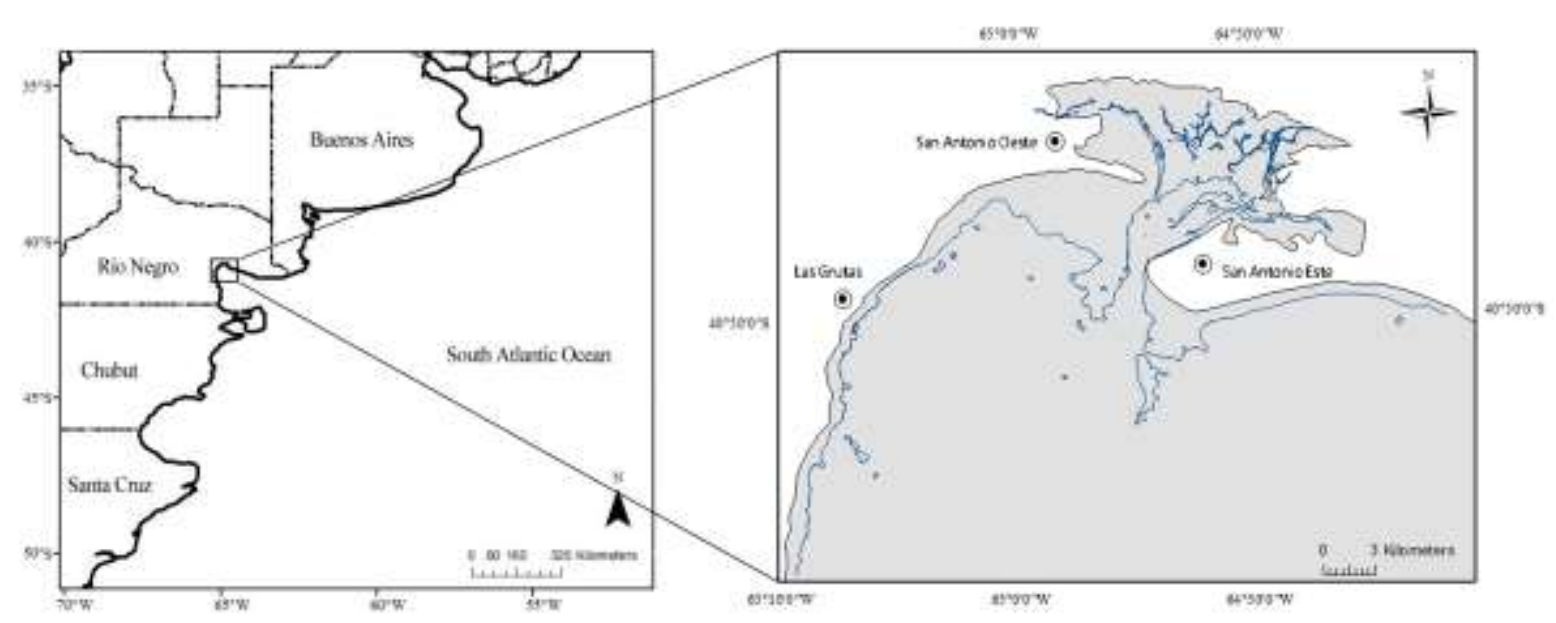

Fig. 1. Left: Map of Argentina indicating the location of the study area, Bahía San Antonio (BSA). Provinces are also indicated. Right: Map of BSA indicating the three urbanised areas. Contour line of the bay indicates the shoreline at high tide, the isobath indicates the shoreline at low tide. 


\section{Fieldwork}

Between August 2008 and December 2011, boat-based surveys were conducted from a small outboard-powered inflatable boat. All survey effort was restricted to calm seas of Beaufort state $\leq 3$, periods of no precipitation and good visibility. During each survey, the boat was maintained at a steady speed of 4-5 knots. This slow speed was possible due to the environmental conditions in the area (lack of a large swell, often flat sea conditions) and the relative small size of the study area; i.e. it improved the chances to spot dolphins while having enough time to sample large portions of the study area. During the surveys, the same 2-3 observers maintained a continuous visual search for dolphins. Due to logistical limitations, the course of the survey could not be standardised; the area was surveyed non-systematically until a dolphin group was found. Effort was logged using the automatic tracking system of a hand held Geographical Positioning System (GPS) Garmin Etrex and GPSmap 62s.

Once a bottlenose dolphin group was encountered, the speed of the vessel was changed to match the pace of the group. A bottlenose dolphin group was defined as a collection of dolphins within a $100 \mathrm{~m}$ radius of each other that operated in a coordinated way (Lusseau et al., 2003), interacting or engaged in similar activities (Irvine et al.,1981; Wells et al., 1987; Wilson, 1995; Lusseau et al., 2006; Connor et al., 2000). Once a bottlenose dolphin group was encountered, group composition was determined; groups were classified as either "groups with calves" or "groups without calves". Calves were defined as being up to $2 / 3$ the length of an adult, with or without foetal folds (Mann \& Smuts, 1999) and commonly swimming in close association with an adult (Shane, 1990). A dolphin group was followed until it was out of sight. When a dolphin group split up, a sub-group was arbitrarily chosen and followed based on a variety of factors such as e.g. direction of travel, weather conditions, presence of interesting individuals (e.g., a new born calf), etc.

Data on the behaviour of dolphin groups were gathered using a focal group 5-min point sampling mode (Altmann, 1974; Mann, 1999). For each sample, the predominant activity of the majority of the group (>50\%) was recorded. The behavioural categories used are summarised in Table 1. Along with behavioural data, in situ GPS positions and depths (when an echo-sounder was available) were recorded every 5 min in the presence of dolphins using a hand-held GPS Garmin Etrex and GPSmap 62s, and the vessel's echo-sounder respectively. 
Table 1. Definitions of behavioural categories used in this study (adapted from Shane, 1990; Bearzi et al., 1999; Bearzi, 2005).

\begin{tabular}{ll}
\hline Travel & Moving steadily in one direction. \\
Surface-feeding & Feeding activities performed close to water surface, typical fast moving in circles at the \\
& surface. Fish are seen to jump out of the water (birds concentrating over the dolphins). No \\
& physical contact between individuals can be observed. \\
& Tail-out dives longer than 30 s occurring during the 5 min sample. The 30 s cut of was chosen \\
Diving & as it was longer than the mean dive duration of 21.8 s measured for coastal bottlenose dolphins \\
& in Argentine waters (Würsig, 1978). No horizontal movements, direction of surfacing \\
Socialising & irregular. Typically followed by two / three breaths after which the next dive commences. \\
& Group members are in frequent physical contact, no steady directional movement, displaying \\
& surface behaviours (e.g. rolling over each other, jumping towards each other). Playful \\
Resting & behaviour, defined as any activity involving a foreign object e.g. kelp tossing was included in \\
Not classified & this category (Shane et al., 1986). \\
& Moving in varying directions in one general location, no surface behaviours, no physical \\
Milling & Lontact can be observed.
\end{tabular}

\section{Analyses}

ESRI ArcGIS version 10.1 was used to subdivide the study area into grid cells of $1 \mathrm{~km}^{2}(1 \mathrm{~km} \times 1 \mathrm{~km})$. Due to the relative homogeneity in the area this was believed to give sufficient detail for this study. Cells with a total survey effort lower than a cell's diagonal (1414 m) were excluded from analysis. WGS 1984 UTM zone 20S was used as the projected coordinate system.

Subsequently, each cell was attributed a value of 3 environmental variables; depth, slope and substrate. The mean depth (hereafter $M D$ ) and substrate type were extracted from an electronic bathymetrical chart obtained from the Naval Hydrographical Service of Argentina.

(1) Depth: The $M D$ value for each cell was obtained by averaging the $M D$ values marked on the chart within each cell (Cañadas et al., 2002). The $M D$ value reflects a depth range $\pm 4.15 \mathrm{~m}$ depending on tide (considering the mean tidal amplitude of $8.3 \mathrm{~m}$ in the study area). Therefore, the intertidal zone was defined as all cells with a $M D<4 \mathrm{~m}$, whereas cells with $M D \geq 4 \mathrm{~m}$ were defined as the subtidal zone. 
Additionally, exact depth measurements recorded in the field were analysed to assess exact depths at which dolphins were encountered. Due to logistical limitations this could only be done for 41 dolphin groups. In order to check for the reliability of $M D$ data, a Pearson's correlation coefficient was calculated between $M D$ and the measured depth values in the corresponding grid cells.

(2) Slope: Slope, expressed in degrees, was calculated as $\left(D_{\max }-D_{\min }\right) / D I$ where $D_{\max }$ is the maximum depth of the cell, $\mathrm{D}_{\min }$ is the minimum depth of the cell and DI the distance between the points of maximum and minimum depth of the cell (Cañadas et al., 2002; Garaffo et al., 2007).

(3) Substrate: Substrate type (sand, rocky flats, gravel or shells) was attributed to each cell according to the substrate most commonly found in each cell.

To test whether variables in the cells were spatially auto-correlated, and thus not independent, Moran's I index was calculated for the encounter rate of dolphin groups using the Spatial Statistics Tool in ArcGIS. To correct for the potential bias of non-systematic surveys, an encounter rate of dolphin groups was calculated as $n / \mathrm{L}$ where $n$ is the number of dolphin groups encountered in each grid cell (i.e., first sighting of each dolphin group) and L the total number of kilometres spent on effort in each cell (Bearzi et al., 2005, 2008). To investigate any temporal variation in the encounter rate, Kruskal-Wallis and Mann-Whitney U tests were used to test for differences between survey years, seasons and tidal state. For analysis, each survey year was divided into four seasons: summer (January - March), autumn (April - June), winter (July - September), spring (October December). High tide was defined as a $3 \mathrm{~h}$ period including the hour of high tide plus the hour prior and subsequent to it. Accordingly the other tidal phases were defined as follows: low tide is the hour of low tide and the hour prior and subsequent, ebb tide is a $3 \mathrm{~h}$ time period between high and low tide and flood tide is a $3 \mathrm{~h}$ time period between low and high tide.

The influence of the environmental variables $M D$, slope and substrate on the encounter rate of dolphin groups was investigated using a Generalized Linear Model (GLM) in the program R ( $\mathrm{R}$ core team 2016). The number of dolphin groups encountered in each grid cell was set as the response variable with effort in each grid cell (number of km surveyed) as an offset. Given the characteristics of the response variable (counts of dolphin groups), the Poisson distribution and the log-link function were used. Stepwise model selection was performed and the AIC (Akaike Information Criterion) was used as a selection criteria for the best model. A quasi-Poisson GLM model was used to check for over-dispersion of the data (dispersion parameter $\phi>1$ ), whereas model 
validation was achieved by examining the plotted scaled Pearson residuals, and examining the mean-variance relationship and (non-)independence of model residuals.

Considering the large tidal amplitude in the study area, a second GLM was used to investigate the influence of the environmental variables $M D$, slope and substrate on the encounter rate of dolphin groups only during high tide (as it was the only time when both intertidal and subtidal zones were simultaneously available). For this, the number of dolphin groups encountered during high tide was set as the response variable with effort during high tide (number of $\mathrm{km}$ surveyed during high tide) as an offset. Model construction, selection and validation was done in the same way as described above.

Further analysis was conducted to verify if the environmental variables ( $M D$, slope and substrate) varied with group composition (groups with calves vs. groups without calves) and behaviour. To account for nonindependence of 5-min behavioural samples, only the first behavioural sample of each group was used in analysis. Kruskal-Wallis and Mann-Whitney $U$ tests were employed to assess whether different groups compositions and behaviours were observed in areas with different $M D$ and slopes. A $\chi^{2}$ of independence was used to test whether different group compositions and behaviours were observed in areas with different types of substrate. In order to investigate the difference in behaviour observed in the intertidal vs. subtidal zone, a contingency table was created for the initial behaviour observed for each dolphin group, considering only those groups observed during high tide (when both intertidal and subtidal areas were available simultaneously). A Pearson's $\chi^{2}$ test was then used as the test statistic.

\section{RESULTS}

\section{Effort}

A total of 129 non-systematic boat-based surveys were conducted between 2008 and 2011, resulting in $586 \mathrm{~h}$ of survey effort during which 155 dolphin groups (DG) were observed (Table 2). 
Table 2. Hours of boat-based survey effort over the different seasons.

\begin{tabular}{ccccc}
\hline & Summer & Autumn & Winter & Spring \\
\hline $\mathbf{2 0 0 8}$ & $/$ & $/$ & 30.9 & 52.6 \\
$\mathbf{2 0 0 9}$ & 67.3 & 40.3 & 36.8 & 17.6 \\
$\mathbf{2 0 1 0}$ & 31.0 & 14.0 & 143.1 & 21.8 \\
$\mathbf{2 0 1 1}$ & 77.9 & 32.6 & 19.6 & $/$ \\
TOTAL & $\mathbf{1 7 6 . 2}$ & $\mathbf{8 7}$ & $\mathbf{2 3 0}$ & $\mathbf{9 2}$
\end{tabular}
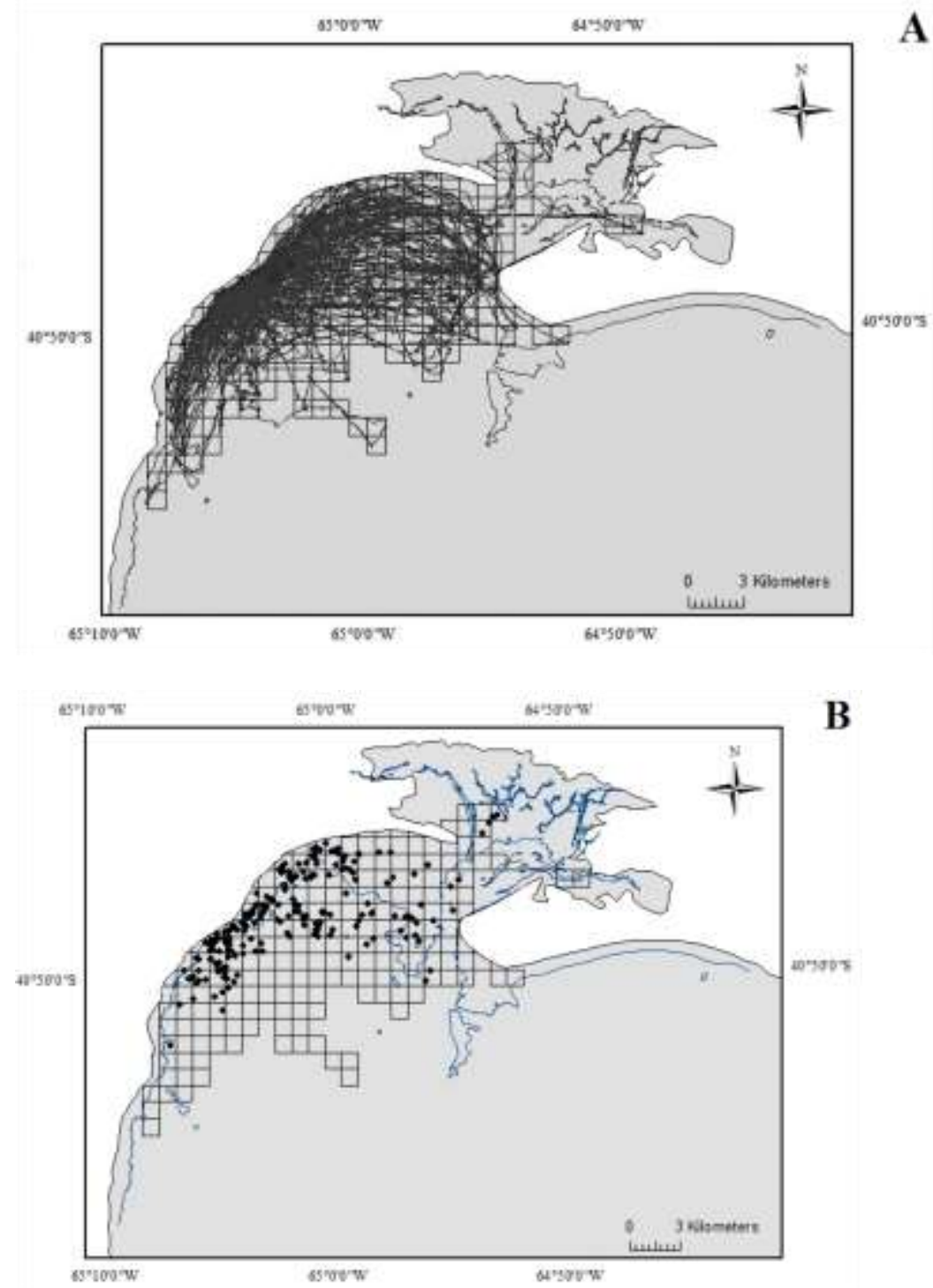

Fig. 2. A) Survey effort tracks in Bahía San Antonio, indicating the 245 grid cells covered. B) geographic positions of initial sightings of 155 bottlenose dolphin groups within 66 of the surveyed grid cells. Contour line delineate the intertidal area 
In total, 245 grid cells were used in analysis (or $233 \mathrm{~km}^{2}$ excluding surface of grids overlapping land; Figure 2A). Of these grid cells, 102 were located in the intertidal zone whereas the other 143 were located in the subtidal region. Bottlenose dolphin groups were initially sighted in 66 of these grid cells (Figure 2B) and were followed over a total of 127 grid cells or $121 \mathrm{~km}^{2}$ (51\% of surveyed area). Of these 66 grid cells, 21 were in the intertidal zone whereas the other 45 were located in the subtidal zone.

Survey effort during high tide only (61 surveys) covered a total of 176 grid cells, of which 72 and 103 were located in the intertidal and subtidal zone respectively. During these surveys, 28 dolphin groups were encountered in 13 grid cells, of which ten were located in the intertidal zone and 3 in the subtidal region. Table 3 provides an overview.

Table 3. The number of grid cells covered by the survey effort and dolphin groups encounters. DG = dolphin groups

\begin{tabular}{cccc}
\hline & $\begin{array}{c}\text { Total \# } \\
\text { grid cells }\end{array}$ & $\begin{array}{c}\text { \# grid } \\
\text { cells } \\
\text { intertidal } \\
\text { zone }\end{array}$ & $\begin{array}{c}\text { \# grid } \\
\text { cells } \\
\text { subtidal } \\
\text { zone }\end{array}$ \\
\hline Total effort & 245 & 102 & 143 \\
DG encounters & 66 & 21 & 45 \\
\hline Effort High Tide & 176 & 72 & 103 \\
DG encounters High Tide & 13 & 10 & 3 \\
\hline
\end{tabular}

\section{Encounter rate}

The median encounter rate was 0.02 or 2 dolphin groups encountered every $100 \mathrm{~km}$ surveyed (average $=0.01$; quantile values $\mathrm{Q} 1=1.3$; $\mathrm{Q} 3=2.8$ ). Moran's I index calculated for the encounter rates was not significantly different from zero $(z=0.12 ; p>0.05)$ indicating that cells were not spatially auto-correlated. No significant variations in encounter rate were found across the different study years $(\mathrm{H}=3.2, p=0.36)$, seasons $(\mathrm{H}=4.13 ; p$ $=0.24)$ or tidal states $(\mathrm{H}=0.46, p=0.93)$.

Data was not over-dispersed (dispersion parameter $\phi=0.54$ ). The best fitting model of the Poisson GLM analysis indicated an importance of the variable substrate on the overall dolphin encounter rate (Table 4a). As such, dolphins were encountered more often over sandy substrates. However, AIC values did not differ largely when removing all variables from the model, suggesting a relatively low influence of any environmental variable on the overall dolphin encounter rate. On the other hand, the GLM analysis of the data collected during high tide showed an importance of $M D$ on the dolphin encounter rate (Table 4b). As such, models excluding $M D$ had 
substantially larger AIC values. Model validation was performed in both GLM analyses and indicated the models were deemed appropriate.

Table 4. Ranked Generalized Linear Models assessing the relationship between the environmental variables $M D$, slope and substrate on the encounter rate of dolphin groups (DG). Parameters include: degrees of freedom $(d f)$, Akaike Information Criterion (AIC), delta Akaike Information Criterion ( $\triangle \mathrm{AIC}$ ) and Weight.

\begin{tabular}{|c|c|c|c|c|}
\hline Total & $d f$ & $\mathrm{AICc}$ & $\Delta \mathrm{AIC}$ & Weight \\
\hline DG $\sim$ Substrate + offset $(\log ($ Effort $))$ & 3 & 244.2 & 0.00 & 0.32 \\
\hline $\mathrm{DG} \sim \operatorname{offset}(\log ($ Effort $))$ & 1 & 245.1 & 0.89 & 0.20 \\
\hline $\mathrm{DG} \sim \mathrm{MD}+$ Substrate + offset $(\log ($ Effort $))$ & 4 & 245.8 & 1.62 & 0.14 \\
\hline DG $\sim$ Slope + Substrate + offset $(\log ($ Effort $))$ & 4 & 246.3 & 2.09 & 0.11 \\
\hline DG $\sim$ Slope + offset $(\log ($ Effort $))$ & 2 & 247.1 & 2.88 & 0.08 \\
\hline $\mathrm{DG} \sim \mathrm{MD}+$ offset $(\log ($ Effort $))$ & 2 & 247.1 & 2.91 & 0.07 \\
\hline $\mathrm{DG} \sim \mathrm{MD}+$ Slope + Substrate + offset $(\log ($ Effort $))$ & 5 & 248.0 & 3.74 & 0.05 \\
\hline DG $\sim$ MD + Slope + offset $(\log ($ Effort $))$ & 2 & 249.1 & 4.93 & 0.03 \\
\hline \multicolumn{5}{|l|}{ B } \\
\hline High Tide & $d f$ & AICc & $\triangle \mathrm{AIC}$ & Weight \\
\hline $\mathrm{DG} \sim \mathrm{MD}+\operatorname{offset}(\log ($ Effort $))$ & 2 & 85.0 & 0.00 & 0.57 \\
\hline $\mathrm{DG} \sim \mathrm{MD}+$ Slope + offset(log(Effort $))$ & 3 & 86.9 & 1.88 & 0.22 \\
\hline $\mathrm{DG} \sim \mathrm{MD}+$ Substrate + offset(log(Effort $))$ & 4 & 87.8 & 2.80 & 0.14 \\
\hline $\mathrm{DG} \sim \mathrm{MD}+$ Slope + Substrate $+\operatorname{offset}(\log ($ Effort $))$ & 5 & 90.2 & 5.15 & 0.04 \\
\hline DG $\sim$ Slope + offset $(\log ($ Effort $))$ & 2 & 99.2 & 14.17 & 0.00 \\
\hline DG $\sim$ Slope + Substrate + offset $(\log ($ Effort $))$ & 4 & 103.1 & 18.10 & 0.00 \\
\hline DG $\sim$ Substrate + offset $(\log ($ Effort $))$ & 3 & 103.5 & 18.43 & 0.00 \\
\hline
\end{tabular}

Investigating further the relation between encounter rates and the $M D$, it was notable that overall encounter rates dropped substantially at $M D>9 \mathrm{~m}$ deep, equalling 0 at $M D \geq 13 \mathrm{~m}$ deep (Figure 3a). During high tide, encounter rate were significantly higher in the intertidal zone $(M D<4 \mathrm{~m}$ deep) than in the subtidal region $(M D \geq 4 \mathrm{~m}$ deep; Figure $3 b ; U=1548, p<0.01)$. Accordingly, specific depth values measured in the field in the presence of dolphins ( $\mathrm{n}=41$ groups) never exceeded $10 \mathrm{~m}$ (median depth = 5.8 m; quantile values $\mathrm{Q} 1=4.1 \mathrm{~m} ; \mathrm{Q} 3=7.2 \mathrm{~m}$; range: $0.8 \mathrm{~m}$ to $10 \mathrm{~m}$ ). These measured depth values were positively correlated to the $M D$ of the corresponding grid cells $\left(\mathrm{r}^{2}=0.51, p<0.01\right)$ indicating the reliability of $M D$ values. Slope and $M D$ were weakly correlated in the grid cells $\left(\mathrm{r}^{2}=0.25, p<0.05\right)$. 

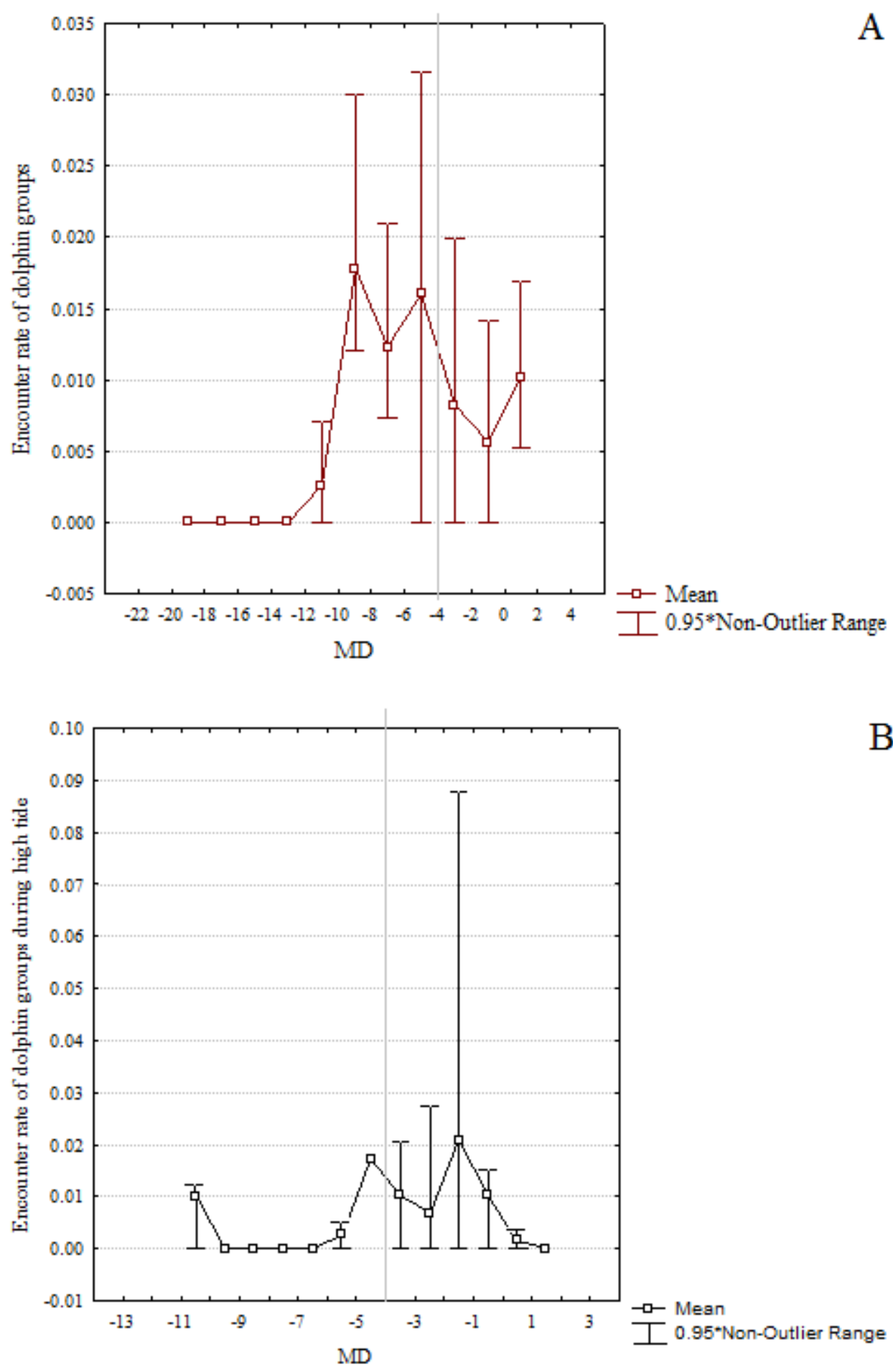

Fig. 3. Variation in encounter rate of dolphin groups according to the $M D$ of surveyed cells. The line indicates the transition from intertidal to subtidal zone. A) In general, B) During high tide.

\section{Group composition and behaviour}

In total, $61 \%$ of the encountered groups contained calves ( $\mathrm{n}=95$ groups). No significant variation could be found in the environmental variables of where these groups were encountered, when compared to groups without 
calves $\left(M D \mathrm{U}=3800, p=0.73\right.$; slope $\mathrm{U}=3622, p=0.44 ;$ substrate $\left.\chi^{2}=0.28, p=0.96\right)$. Similarly, depth values measured in the field did not vary between groups with calves $(n=27)$ and groups without calves $(n=14 ; U=$ $1.31, p=0.19)$.

However, depth changed significantly with the behaviour of dolphins $(M D: \mathrm{H}=26.3, p<0.01$; measured depths: $\mathrm{H}=61.9, p<0.01$; Figure 4). Additional Mann-Whitney $\mathrm{U}$ tests showed that diving, feeding and travelling behaviour occurred in deeper areas, whereas resting, milling and socialising were observed in significantly shallower regions.

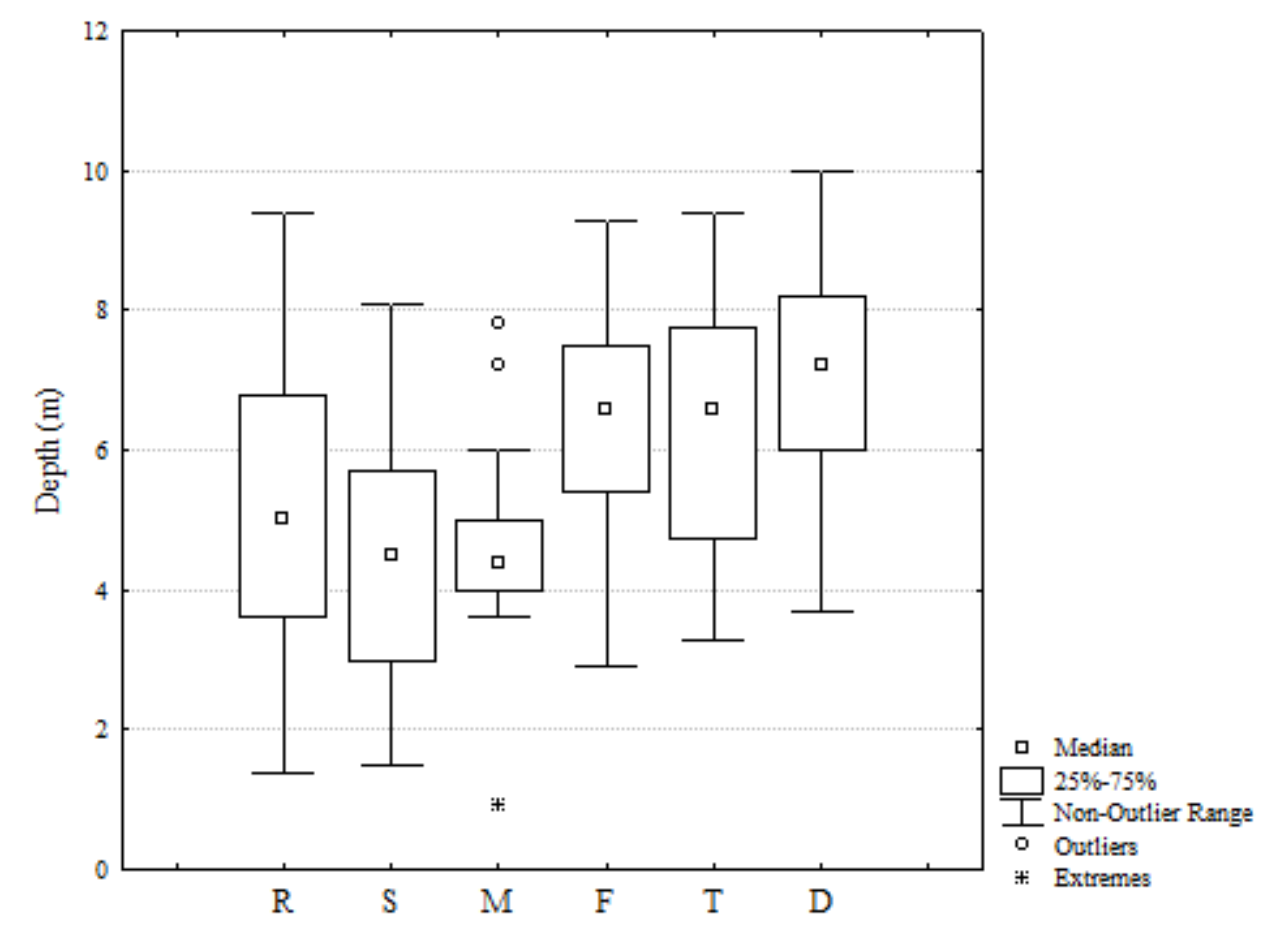

Fig. 4. Depth values measured in the field ( $n=41$ dolphin groups) for different behavioural states: $R=$ resting, $S=$ socialising, $\mathrm{M}=$ milling, $\mathrm{F}=$ surface feeding, $\mathrm{T}=$ travel, $\mathrm{D}=$ diving

Diving occurred over steeper slopes than all other behaviours $(\mathrm{H}=17.6, p<0.01)$. There was no significant variation in substrate for the different behaviours $\left(\chi^{2}=17.3, p=0.50\right)$. During high tide, most dolphins groups encountered in the intertidal zone were surface feeding, whereas in the subtidal region most were diving $(\chi 2=$ 14.4, $p<0.05 ;$ Figure 5). 


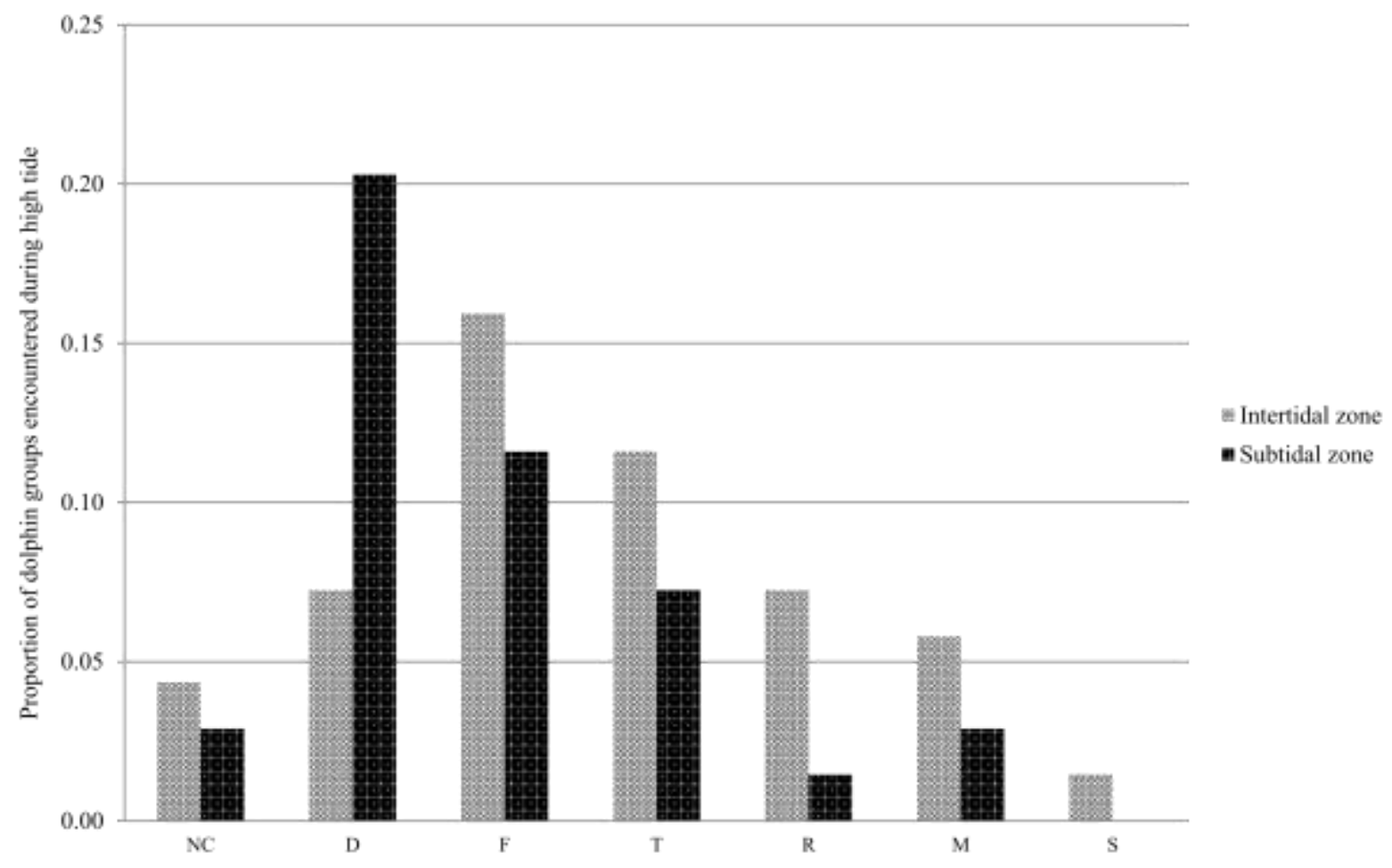

Fig. 5. Proportion of dolphin groups encountered during high tide and their respective behaviours in the intertidal vs. subtidal zone: $\mathrm{NC}=$ not classified, $\mathrm{D}=$ diving, $\mathrm{F}=$ surface feeding, $\mathrm{T}=$ travelling, $\mathrm{R}=$ resting, $\mathrm{M}=$ milling, $\mathrm{S}=$ socialising

\section{DISCUSSION}

Due to the large tidal amplitude and the extended intertidal habitat in the study area, the region offers an ideal scenario to study the use of intertidal habitat by bottlenose dolphins. However, although data was carefully selected to account for possible bias, data were collected during a photo-identification study and therefore may have limitations. Results should therefore be interpreted with care.

Overall, bottlenose dolphins were observed in only half of the surveyed area, and remained in relatively shallow waters. During high tide, depth appeared to be an important factor affecting the dolphins' habitat use patterns. As such, when the intertidal zone was immersed during high tide, dolphins clearly moved to this area. The only other study conducted in Argentina on the topic indicated similar movements of bottlenose dolphins related to the tide (Würsig \& Würsig, 1979). In general, tidal flow is known to affect short-term movement in coastal bottlenose dolphins (e.g. Irvine \& Wells, 1972; Shane et al., 1986; Shane, 1990; Acevedo, 1991; Hanson \& Defran, 1993; Chilvers et al., 2003). As such, the species is commonly present in very shallow waters (e.g. Würsig \& Würsig, 1979; Leatherwood \& Reeves, 1983; dos Santos \& Lacerda, 1987; Ballance, 1992; Wilson et 
al., 1997; Defran \& Weller, 1999; Ingram \& Rogan, 2002). This has often been related to a trade-off between food availability and predation risk (Heithaus \& Dill, 2002). Predation risk was reported to be low in the study area (Vermeulen \& Bräger, 2015). Therefore food availability is hypothesised to be one of the main driving factors behind the observed use of the intertidal zone, an idea supported by the large number of dolphin groups engaged in foraging activities in this part of their habitat.

Although intertidal habitats generally represent only a small proportion of the marine environment, they often sustain a high biodiversity of organisms. Due to the large extension of BSA's intertidal zone, it has already been nationally and internationally recognized for its high value as a feeding ground for migrating shore birds (e.g. González et al., 1996; DiGiacomo, 2005). Similarly, Perier (1994) reported on the importance of BSA’s intertidal zone as a foraging (and spawning) ground for multiple fish species. The presented study indicates a similar significance of this intertidal habitat for the bottlenose dolphins, suggesting they are an integral part of the intertidal food web. Indeed, it was previously reported that the many invertebrate species inhabiting an intertidal zone may serve as an important food source attracting predators up the food chain (e.g. González, 1993; Perier, 1994; Garcia et al., 2010). Such an exploitation of resources in the intertidal zone during its immersion at high tide has also been recorded for several other coastal marine mammal species around the world, including for example Indo-Pacific humpback dolphins (Sousa chinensis, Lin et al., 2013), marine tucuxi (Sotalia fluviatilis, Gurjão et al., 2003), finless porpoises (Neophocaena phocaenoides, Singh, 2003), marine otters (Lutra felina, Medina-Vogel et al., 2006), dugongs (Dugong dugong) and manatees (Trichechus sp.) (Gibson et al., 2003).

However, humans are often also highly dependent on intertidal habitats. This frequently leads to strong environmental pressures and conservation related issues (e.g. Litler, 1980; Brosnan \& Crumrine, 1994; Addessi, 1995; Thompson et al., 2002; Keough et al., 2002). Specifically in BSA, continued anthropogenic activities have shown to affect the invertebrate community of the local intertidal habitat through eutrophication (Garcia et al., 2010), pollution (Gil et al., 1996, 1999, 2006; Bonuccelli et al., 2004; Vázquez et al., 2007) and habitat degradation (Gil et al., 2006, Carbone et al., 2011). How this affects predators up the food chain remains unknown. However, as large marine predators are often good indicators for ecosystem health (e.g. Agrawal, 2011), understanding the ecological importance of the intertidal habitat for bottlenose dolphins is of great value for further in depth research and enhanced impact assessments. This in turn will be essential to ensure accurate 
conservation management in the area, not only positively affecting this vulnerable population of bottlenose dolphins but also a wide range of other marine and coastal (often less charismatic) species under its shadow. In the end, management of intertidal habitat may arguably be easier than of open sea, as access can be restricted and implementation of regulations more strictly controlled (Thompson et al., 2002).

\section{ACKNOWLEDGEMENTS}

Special thanks go to Alejandro Cammareri and the Marybio Foundation, from which I was part during the course of the study. Also thanks to Mariela Pazos, Jorge Baraschi, Hernan David and Natalia Sarra for their help and support. Thanks to the environmental Agency of Río Negro (Consejo de Ecología y Medio Ambiente de la Provincia Río Negro [CODEMA]) and the Wildlife Service of Río Negro (Dirección de Fauna de la Provincia Río Negro) for the field permits. Thanks to the Naval Hydrographical Service of Argentina for the detailed electronic bathymetrical chart of the study area. The manuscript was improved thanks to the review of Stefan Bräger, Jonas Tundo, Pedro Fruet, Sarah Dwyer and Tilen Genov.

\section{FINANCIAL SUPPORT}

The funding received for this research was very limited as there was no $\mathrm{PhD}$ scholarship available for the corresponding author. Most funds came from investments of personal money. Received funds came from the following organisations: Cetacean Society International (www.csiwhalesalive. com): US\$3,000 was given for the completion of fieldwork in 2007 and 2008. No specific grant number is available; Trigon N.V. (www.trigon.be): This software company contributed to the project by donating portable computers and hard drives and Marybio Foundation: The Marybio foundation was the NGO the corresponding author created and directed over the course of the study period. With this NGO, the corresponding author was able to receive the above-mentioned funds, gather membership fees, and receive students who contributed to the project with work (for their dissertation research) and funds from their respective universities. The funders of this research had no role in study design, data collection and analysis, decision to publish, or preparation of the manuscript. 


\section{REFERENCES}

Acevedo A. (1991) Behaviour and movements of bottlenose dolphins, Tursiops truncatus, in the entrance to Ensenada De La Paz, Mexico. Aquatic Mammals 17, 137-147.

Acevedo A. and Würsig B. (1991) Preliminary observations on bottlenose dolphins, Tursiops truncatus, at Isla del Coco, Costa Rica. Aquatic Mammals 17, 148-151.

Addessi L. (1995) Human disturbance and long-term changes on a rocky intertidal community. Oceanographic Literature Review 6, 503.

Agrawal A. (2011). Trophic Cascades: Predators, Prey, and the Changing Dynamics of Nature. The Quarterly Review of Biology 86, 127.

Altmann J. (1974) Observational study of behaviour: Sampling methods. Behaviour 49, 227-265.

Ballance L.T. (1992). Habitat use patterns and ranges of the bottlenose dolphin in the Gulf of California, Mexico. Marine Mammal Science 8, 262-274.

Bearzi G., Politi E. and Notarbartolo di Sciara G. (1999) Diurnal behavior of free-ranging bottlenose dolphins in the Kvarneric (Northern Adriatic Sea). Marine Mammal Science 15, 1065-97.

Bearzi M. (2005) Aspects of ecology and behaviour of bottlenose dolphins (Tursiops truncatus) in Santa Monica Bay, California. Journal of Cetacean Research and Management 7, 75-83.

Bearzi G., Azzellino A., Politi E., Costa M. and Bastianini M. (2008) Influence of seasonal forcing on habitat use by bottlenose dolphins Tursiops truncatus in the Northern Adriatic Sea. Ocean Science Journal 43, 175-182.

Blasi M.F. and Boitani L. (2012) Modelling fine-scale distribution of the bottlenose dolphin Tursiops truncatus using physiographic features on Filicudi (southern Thyrrenian Sea, Italy). Endangered Species Research 17, 269-288.

Boltovskoy D. (2009) Atlas de Sensibilidad Ambiental de la Costa y Mar Argentino. http://atlas. ambiente. gov. ar. Consulted on 23th of May 2016. [In Spanish] 
Bonuccelli R., Malan J,. Luna L.I. and Torres L. (2004) Contaminación por metales pesados derivados de la lixiviación de escorias de fundición San Antonio Oeste-Río Negro. IBPM - Serie Publicaciones 3, 63-66

Bräger S., Harraway J.A. and Manly B.F.J. (2003) Habitat selection in a coastal dolphin species (Cephalorhynchus hectori). Marine Biology 143, 233-244.

Brosnan D.M. and Crumrine L.L. (1994) Effects of human trampling on marine rocky shore communities. Journal of Experimental Marine Biology and Ecology 177, 79-97.

Cañadas A., Sagarminaga R. and García-Tiscar S. (2002) Cetacean distribution related with depth and slope in Mediterranean waters off sourthern Spain. Deep-Sea Research Part I 49, 2053-2073.

Cañadas A., Sagarminaga R., de Stephanis R., Urquiola E. and Hammond P.S. (2005) Habitat preference modelling as a conservation tool: proposals for marine protected areas for cetaceans in southern Spanish waters. Aquatic Conservation, Marine and freshwater Ecosystems 15, 495-521.

Carbone M.E., Piccolo M.C. and Perillo G.M.E. (2011) Zonificación ambiental de la reserva natural Bahía San Antonio, Argentina: aplicación del índice de calidad ambiental. Investigaciones Geográficas 56, 49-67.

Chilvers B.L., Corkeron P.J. and Puotinen M.L. (2003) Influence of trawling on the behaviour and spatial distribution of Indo-Pacific bottlenose dolphins (Tursiops aduncus) in Moreton Bay, Australia. Canadian Journal of Zoology 81, 19471955.

Connor R.C., Wells R.S., Mann J. and Read A.J. (2000) The bottlenose dolphin: social relationships in a fission-fusion society. In Mann J., Connor R.C., Tyack P.L. and Whitehead H. (eds) Cetacean societies. University of Chicago Press, Chicago, pp. 91-126.

Defran R.H. and Weller D.W. (1999) Occurrence, distribution, site fidelity, and school size of bottlenose dolphins (Tursiops truncatus) off San Diego, California. Marine Mammal Science 15, 366-380.

DiGiacomo A.S. (2005) Áreas importantes para la conservación de las aves en la Provincia de Río Negro. In DiGiacomo A.S. (ed) Áreas Importantes para la conservación de las Aves en la Argentina. Aves Argentinas and Asociación Ornitológica del Plata: Buenos Aires, pp. 334-349. 
dos Santos M.E. and Lacerda M. (1987) Preliminary observations of the bottlenose dolphins (Tursiops truncatus) in the Sado estuary (Portugal). Aquatic Mammals 13, 65-80.

Garaffo G.V., Dans S.L., Pedraza S.N., Crespo E.A. and Degrati M. (2007) Habitat use by dusky dolphin in patagonia: how predictable is their location? Marine biology 152, 165-177.

García G.O., Isacch J.P., Laich A.G., Albano M., Favero M., Cardoni D.A., Luppi T. and Iribarne O. (2010) Foraging behaviour and diet of American Oystercatchers in a Patagonian intertidal area affected by nutrient loading. Emu 110, 146-154

Giaccardi M. and Reyes L. (2012) Plan de Manejo del Área Natural Protegida Bahía de San Antonio, Rio Negro. Gobierno de la Provincia de Río Negro.

Gibson R.N., Barnes M. and Atkinson R.J.A. (2003) Mammals in intertidal and maritime ecosystems: interactions, impacts and implications. Oceanography and Marine Biology 40, 491.

Gil M., Harvey M., Commendatore M., Colombo J.C. and Esteves J.L. (1996) Evaluación de la contaminación por hidrocarburos y metales en la zona costera patagónica. Informe Técnico del Plan de Manejo Integrado de la Zona Costera Patagónica Fundación Patagonia Natural, Chubut, Argentina. Nr 21. ISSN Nº 0328 - 462X

Gil M.N., Harvey M.A. and Esteves J.L. (1999) Heavy metals in intertidal sediments from Patagonian coast, Argentina. Bulleting of Environmental Contamination and Toxicology 63, 52 - 58.

Gil M.N., Torres A., Harvey M. and Esteves J.L. (2006) Metales pesados en organismos marinos de la zona costera de la Patagonia argentina continental. Revista de Biología Marina y Oceanografía 41, 167-176.

González G. and Benseny G. (2013) Consecuencias ambientales del crecimiento demográfico y turístico en Puerto Madryn, Argentina. Pages 169-196 in: Benseny, G. (Ed.) Gestores costeros. De la teoría a la práctica: una aplicación en áreas litorales. Mar del Plata: Universidad Nacional de Mar del Plata. ISBN 978-987-543-755-5.

González P.M., Piersma T. and Verkuil Y. (1996) Food, Feeding, and Refuelling of Red Knots during Northward Migration at San Antonio Oeste, Rio Negro, Argentina. Journal of Field Ornithology 67, 575-591. 
Gurjão L.M., Neto M.F., Santos R.A. and Cascon P. (2003) Feeding habits of marine tucuxi, Sotalia fluviatilis, at Ceará State, northeastern Brazil. Latin American Journal of Aquatic Mammals 2, 117-122.

Hanson M.T. and Defran R.H. (1993) The behaviour and feeding ecology of the Pacific coast bottlenose dolphin, Tursiops truncatus. Aquatic Mammals 19, 127-142.

Heithaus M.R. and Dill L.M. (2002) Food availability and tiger shark predation risk influence bottlenose dolphin habitat use. Ecology 83, 480-491.

Ingram S.N. and Rogan E. (2002) Identifying critical areas and habitat preferences of bottlenose dolphins Tursiops truncatus. Marine Ecology Progress Series 224, 247-255.

Irvine B. and Wells R.S. (1972) Results of attempts to tag Atlantic bottlenosed dolphins (Tursiops truncatus). Biological Systems, Cetology, 13

Irvine A.B., Scott M.D., Wells R.S. and Kaufmann J.H. (1981) Movements and activities of the Atlantic bottlenose dolphin, Tursiops truncatus, near Sarasota, Florida. Fishery Bulletin 79, 671-688.

Keough M.J., Quinn G.P. and King A. (1993) Correlations between human collecting and intertidal mollusc populations on rocky shores. Conservation Biology 7, 378-390.

Leatherwood S. and Reeves R.R. (1983) Abundance of Bottlenose Dolphins in Corpus Christi Bay and Coastal Southern Texas. Contributions to Marine Science 26, 179-199.

Lin T.H., Akamatsu T. and Chou L.S. (2013) Tidal influences on the habitat use of Indo-Pacific humpback dolphins in an estuary. Marine biology 160, 1353-1363.

Litler M.M. (1980) Overview of the rocky intertidal system in Southern California. In Power D.M. (ed) The California islands: proceedings of a multidisciplinary symposium. Santa Barbara Museum of Natural History, Santa Barbara, CA, USA.

Lusseau D., Schneider C., Boisseau O.J., Haase P., Slooten E. and Dawson S.M. (2003) The bottlenose dolphin community of Doubtful Sound features a large proportion of long-lasting associations. Can geographic isolation explain this unique trait? Behavioral Ecology and Sociobiology 54, 396-405. 
Lusseau D., Slooten L. and Currey R.J. (2006) Unsustainable dolphin-watching tourism in Fiordland, New Zealand. Tourism in Marine Environments 3, 173-178.

Mann J. (1999) Behavioural sampling methods for cetaาceans: A review and critique. Marine Mammal Science 19, $102-122$.

Mann J. and Smuts B. (1999) Behavioural development in wild bottlenose dolphin newborns (Tursiops sp.). Behaviour 136, 529-566.

Medina-Vogel G., Rodriguez C.D., Alvarez R.E. and Bartheld J.L.V. (2006) Feeding ecology of the marine otter (Lutra felina) in a rocky seashore of the south of Chile. Marine Mammal Science 20, 134-144.

Peralta C. (1998) Aspectos sociales de la Patagonia. Capitula de Patagonia XXI Informe de consultora DHV, Comunicacion Tecnica 173. ISSN 1667-4006. INTA-EEA Bariloche.

Perier M.R. (1994) La fauna íctica en el litoral de la Bahía de San Antonio (Golfo San Matias, Provincia de Río Negro). Dissertation, Facultad de Ciencias naturales y Museo, Universidad Nacional de La Plata, Argentina. 175 pp.

R Core Team (2016). R: A language and environment for statistical computing. R Foundation for Statistical Computing, Vienna, Austria. https://www.R-project.org/

Shane S.H. 1990. Behaviour and ecology of the bottlenose dolphin at Sanibel Island, Florida. In Leatherwood S. and Reevers R.R. (eds) The bottlenose dolphin. Academic Press, San Diego, CA, pp. 245-266.

Shane S.H., Wells R.S. and Würsig B. (1986) Ecology, behavior and social organization of the bottlenose dolphin: a review. Marine Mammal Science 2, 34-63.

SHN (2000). Derrotero Argentino, parte II: Costa del Atlentico. Servicio de Hydrografía Naval, Armada de la Republica Argentina (Argentine Navy), Buenos Aires, Argentina.

Scott M.D., Wells R.S. and Irvine A.B. (1996) Long-term studies of bottlenose dolphins in Florida. IBI Report 6, 73-80.

Singh H.S. (2003) Sea mammals in marine protected area in the Gulf of Kachchh, Gujarat State, India. Indian Journal of Marine Science 32, 258-262. 
Thompson R.C., Crowe T.P. and Hawkins S.J. (2002) Rocky intertidal communities: past environmental changes, present status and predictions for the next 25 years. Environmental Conservation 29, 168-191.

Vázquez N.N., Gil M.A., Esteves J.L. and Narvate M.A. (2007) Monitoring Heavy Metal Pollution in San Antonio Bay, Río Negro, Argentina. Bull Environ Contam Toxicol 79, 121-125

Vermeulen E. and Cammareri A. (2009) Residency Patterns, Abundance and Social composition of Bottlenose Dolphins (Tursiops truncatus) in Bahía San Antonio, Patagonia, Argentina. Aquatic Mammals 35, 379-386.

Vermeulen E. and Bräger S. (2015) Demographics of the Disappearing Bottlenose Dolphin in Argentina: A Common Species on Its Way Out? PLoS ONE 10: e0119182. doi:10.1371/journal.pone.0119182.

Vermeulen E, Balbiano A, Beleguer F, Colombil D, Failla M, Intrieri E, Bräger S. (2016) Site-fidelity and movement patterns of bottlenose dolphins in central Argentina: essential information for effective conservation. Aquatic Conservation DOI: $10.1002 /$ aqc. 2618

Waples D.M. (1995) Activity budgets of free-ranging bottlenose dolphins (Tursiops truncatus) in Sarasota Bay, Florida. MSc thesis. University of California Santa Cruz, USA.

Wells R.S., Scott M.D. and Irvine A.B. (1987) The social structure of free-ranging bottlenose dolphins. In Genoways H.H. (ed) Current Mammalogy Vol 1. Plenum Press, New York, pp. 247-305.

Wilson B. (1995) The ecology of bottlenose dolphins in the Moray Firth, Scotland: a population at the northern extreme of the species' range. $\mathrm{PhD}$ thesis. University of Aberdeen, Scotland.

Wilson B., Thompson P.M. and Hammond P.S. (1997) Habitat use by bottlenose dolphins: seasonal distribution and stratified movement patterns In Moray Firth, Scotland. Journal of Applied Ecology 34, 1365-1374.

Würsig B. (1978) Occurrence and group organization of Atlantic bottlenose porpoise (Tursiops truncatus) in an Argentine bay. Biological Bulletin 154, 348-359.

Würsig B. and Würsig M. (1979) Behaviour and ecology of bottlenose porpoises, Tursiops truncatus, in the South Atlantic. Fishery Bulletin 77, 399-442. 